\title{
BIOREMEDIATION OF AGRICULTURAL SOIL CONTAMINATED BY A CRUDE OIL SPILL
}

\author{
ALI, W. A. ${ }^{1 *}-$ FARID, W. A. ${ }^{1}-$ AL-SALMAN, A. N. K. ${ }^{2}$ \\ ${ }^{1}$ Department of Community Health Technology, College of Health and Medical Technology in \\ Basrah, Southern Technical University, Basrah, Iraq \\ (e-mail:wisam710@yahoo.com; phone: +964-77-0310-6873) \\ ${ }^{2}$ Department of Pathology and Poultry, Veterinary College, University of Basrah, Basrah, Iraq \\ (e-mail: aseelnk1979@gmail.com; phone: +964-77-3011-1274) \\ *Corresponding author \\ e-mail:wasen336@yahoo.com; phone: +964-77-1493-9973 \\ (Received 29 Jul 2019; accepted 25 $5^{\text {th }}$ Nov 2019)
}

\begin{abstract}
A local oil spill is the main cause of hydrocarbon soil pollution. Biological treatment of oil polluted soil may be possible due to the presence of oil-utilizing microorganisms at the site. Several factors affecting soil oil degradation include hydrocarbons solubility, soil texture, ventilation, oil toxicity, availability of nutrients, etc. Many techniques are used in the bioremediation of oil polluted soil. In this study, the compost system was used to increase the oxygen transmission with the addition of nutrients (NPK), hay (bulking agent) and biosurfactants producing bacteria (B. cereus WR146) to enhance the hydrocarbons degradation in agricultural soil. After 3 months of biological treatment, crude oil content decreased to3.73-2.42\% from the initial $4.20 \%$. The percentage of crude oil degradation ranged from 20.1-44.5 depending on the treatment method used. Carbon dioxide development rates ranged from 30.6$55.0 \mu \mathrm{g} \mathrm{g}^{-1}$ day $^{-1}$, indicating a significant crude oil degradation due to aerobic microorganisms. There is no clear picture of whether nutrients and bulking agent increase the crude oil degradation rates in the current study. The results indicate that the bioremediation of soil polluted with crude oil is more efficient when using compost system, good ventilation, nutrients, and biosurfactants producing bacteria.
\end{abstract}

Keywords: biodegradation, oil pollution, agricultural soil, biosurfactants, bacteria

\section{Introduction}

Oils are the main source of energy in most industries and modern life. Leakages and accidental spills of oil and its products occur throughout production, export, refining, transport and storage. The quantity of leaking crude oil is estimated at 600,000 metric tons per year at the rate of 200,000 metric tons annually (Prathyusha et al., 2016). The introduction of hydrocarbons into the environment is one of the main causes of water and soil pollution. Hydrocarbons reach soils (including agricultural soils) from a variety of natural and anthropogenic sources. Technological hydrocarbons penetrate the soil after the soil surface is contaminated with crude oil and its products and hydrocarboncontaining materials. One of the most common anthropogenic sources is the leakage of underground storage tanks. Other major sources include spillage during refueling and lubrication. Sites where transportation and handling of crude oil are potential places for oil pollution. Shale oil retorting plants provide another source of hydrocarbon pollution (Boitsov et al., 2011; Pinedo et al., 2014; Ivshina et al., 2015). Although most of the hydrocarbons in the soil environment are of an anthropogenic nature, there are some natural sources of these substances. These may include the hydrocarbons resulting from the biogeochemical processes in the soil and those that migrate from the deep, oilbearing ground layers. It also includes hydrocarbons released from the biodegradation 
of organic matter. There is also accumulated evidences that some organisms, especially higher plants, are capable of synthesizing certain hydrocarbons that may also find their way into the soil. However, the natural sources are fairly simple and are unlikely to cause significant hydrocarbon pollution of the soil (Biache et al., 2014; Gennadiev et al., 2015). Soil contamination with petroleum hydrocarbons adversely affects human and animal health and plant production as most substances are toxic to living organisms. This contamination can also have long-term implications for soil quality and function and food quality (Agarry and Ogunleye, 2012; Tang et al., 2012; Ng et al., 2017). Most methods used to treat soil pollution include mechanical techniques, burial, vaporization, dispersal and washing. However, these methods are costly and can lead to the imperfect degradation of pollutants (Chee and Shih, 2019).

Bioremediation is defined as the employ of microorganisms to remove environmental contaminants for their various metabolic capacities, a satisfactory and acceptable technique for the removal and degradation of many pollutants, including oil and its products (Adams et al., 2015). Bioremediation technology is thought to be relatively inexpensive and effective (Nwankwegu et al., 2016). Biodegradation by natural microbiological communities is one of the main mechanisms by which oil contaminants can be removed from the environment and are cheaper than other treatment methods (Ron and Rosenberg, 2014).

The prosperity of the oil bioremediation depends on the provision and maintenance of favorable environmental conditions to improve oil degradation. Several researchers have reported several factors affecting the biodegradation rate of oil (Jahangeer and Kumar, 2013; Varjani and Upasani, 2017; Ali, 2019). An important need for bioremediation is the existence of microorganisms with suitable metabolic capacity. If microorganisms are found, optimum growth rates and microbial degradation of hydrocarbons can then be maintained by assuring sufficient nutrient and oxygen concentrations and a $\mathrm{pH}(6-9)$. The physiochemical properties of the oil and area of oil surface are also significant factors for the successful of bioremediation (Eze et al., 2014). The two techniques taken for the bioremediation of oil pollutants are the addition of microorganisms (eligible to degrade hydrocarbons) and surfactants [bioaugumentation], and the modification of the environment by adding fertilizers $(\mathrm{N}$ and $\mathrm{P}$ ) or other cosubstrates limit the growth of microbes and aerating the contaminated site (composting and bulking) [biostimulation] (Ikuesan, 2017). The success of bioremediation attempts to clean up the crude oil spill from the Exxon Valdez tanker in Prince William Sound and the Alaska Gulf in 1989 generated considerable interest in the technology of microbial degradation and remediation (Atlas and Hazen, 2011).

Large numbers of hydrocarbons in crude oil are readily degraded, but others are more stable compounds, which include the hydrocarbons with a large number of methyl substitutes or intensive aromatic rings (Polycyclic Aromatic Hydrocarbon-PAHs) that have low solubility (Šolevic et al., 2011). so as to full degradation of such hydrocarbons must be available for microorganisms and their enzymes.

Surfactants were utilized to elevate the unsolvable organic matter bioavailability (ex. during desorption from solid materials). Surfactants (artificial and natural) were examined with different grades of hit (Biria et al., 2010; Rufino et al., 2014). Persistent organic pollutants can oxidize chemically, but this process seems to be expensive. The incorporation of chemical oxidation and biological remediation should be cost effective, where the primary chemical operation transforms contaminants into low toxic substances and compounds that can be biodegraded (Rufino et al., 2014). 
The compost system with the presence or absence of bulking agents are used to promote oxygen input and improve aerobic biological degradation. In addition, the introduction of microbial nutrients and microorganisms with them can lead to significant degradation of petroleum hydrocarbons (Lukic, 2016; Sari et al., 2019) Most soil systems comprise oil-utilizing bacteria and fungi (Ikuesan, 2017; Ali, 2019), but their counts and metabolic characteristic could not be important. The bioaugmentation permits the addition of microbes with suitable metabolic capacity and an increase in the microbial community that can accelerate the process of bioremediation.

Most of the current studies have focused on assessing the factors that influence bioremediation or experimenting of appropriate products or procedures via the laboratory researches (Das and Chandran, 2011). Only a finite number of field experiences have been given persuasive proof of this technique. In this study, compost systems were examined with the addition of nutrients and microorganisms for the biological treatment of polluted agricultural soil by the leakage of crude oil in southern Iraq.

\section{Materials and methods}

Ten experimental fields were designed in contaminated agricultural soil with an accidental spill of crude oil in the Abu-Al-Khaseeb region $\left(30^{\circ} 27^{\prime} 00^{\prime \prime} \mathrm{N}, 47^{\circ} 59^{\prime} 27^{\prime \prime} \mathrm{E}\right)$ of Basrah province in southern Iraq (Fig. 1), during the Spring of 2018. The oil spill covered about $500 \mathrm{~m}^{2}$ of agricultural soil and reached a depth of $50 \mathrm{~cm}$. The measurement of each designed field was $4 \mathrm{~m}$ length, $4 \mathrm{~m}$ width, and $50 \mathrm{~m}$ depth. The soil of fields was manually drilled using a hoe and shovel at a depth of $50 \mathrm{~cm}$ and turned to mixing crude oil with soil components. The fields were then processed in different increments as shown in Table 1. Some fields were fertilized by NPK $\left(0.015 \mathrm{~kg} \mathrm{~N}_{1} \mathrm{~m}^{-2}, 0.015 \mathrm{~kg} \mathrm{P}_{2} \mathrm{O}_{2} 1 \mathrm{~m}^{-2}\right.$ and $\left.0.015 \mathrm{~kg} \mathrm{~K}_{2} \mathrm{O} 1 \mathrm{~m}^{-2}\right)$ to outdo the restriction of inorganic nutrients. Bermuda grass (Cynodon dactylon L.) hay (chopped to $4.5 \mathrm{~cm}$ size, $p_{\mathrm{b}}$ of $0.019 \mathrm{~g} \mathrm{~cm}^{-3}$ ) was added to some fields at a 1:2 hay:soil volume ratio, as a absorbent agent for crude oil and a bulking agent to promote oxygen transport. The strain, Bacillus cereus WR146 (biosurfactant-producing bacteria), previously isolated from the same site, has been added to fields $\left(25 \mathrm{ml} \mathrm{kg}^{-1}\right.$ soil of bacterial suspension at $1 \times 10^{-6}$ density were sprayed on the field surface) for the production of biosurfactant compounds. The strain was identified using standard biochemical and sugar fermentation test. The species level identification was done using 16S rRNA sequencing. B. cereus WR146 is a gram positive, motile, facultative and spore forming bacterium that can produce biosurfactant in $40{ }^{\circ} \mathrm{C}$ and salinities $25 \%$. These capabilities make it a useful candidate to serve in microbial enhanced oil recovery processes. The purpose of installing of some plastic drainage pipes vertically in some fields was to enhance the transfer of oxygen by forming an air flow in the field based on variations in temperature between the inside of the field and the external atmosphere. Table 2 shows the monthly range and annual average of some environmental factors affecting the soil of the study area, and hence bioremediation.

Three samples were collected from the soil under study prior to the design of the experimental fields to determine the soil properties, assess the level of crude oil pollution and estimate the content of bacteria. The first sample (I) was a soil with little oil pollution. The second (II) was a soil heavily polluted with crude oil. The third (III) was a soil unpolluted with oil located near the spill area. While two soil samples were taken from all experimental fields that were designed to determine the temporal difference in 
populations of bacteria. One of the samples (IV) was from the surface of the field and the other (V) was $50 \mathrm{~cm}$ deep. The IV and V soil samples were taken for each field to take account of evaporation of hydrocarbon and to monitor the bioremediation process at both sites. Each soil sample consisted of five randomly collected samples $(1 \mathrm{~kg})$, each carefully mixed, and $100 \mathrm{~g}$ of each was taken and thoroughly mixed together. Some characteristics of the agricultural soil are given in Table 3.

For the five different samples, $1 \mathrm{~g}$ of soil was used to count heterotrophic bacteria (HB) and oil-utilizing bacteria (OUB) by the standard dilution plate method. The soil was suspended in $99 \mathrm{~mL}$ sterile water, shaken, $120 \mathrm{rpm}$ for $30 \mathrm{~min}$, this stock was used to prepare dilution series, $10^{-1}-10^{-10}$. The HB were counted on nutrient agar medium. The OUB were counted on a solid mineral medium containing as sole sources of carbon and energy, $2 \mathrm{~mL}$ of sterile crude oil into a filter paper lining every Petri-dish cover, and tightly sealing the dish. The mineral medium (MM) was composed of $0.68 \mathrm{~g} \mathrm{~L}^{-1}$ $\mathrm{KH}_{2} \mathrm{PO}_{4}, 1.79 \mathrm{~g} \mathrm{~L}^{-1} \mathrm{HPO}_{4}, 0.35 \mathrm{~g} \mathrm{~L}^{-1} \mathrm{MgSO}_{4}, 1 \mathrm{~g} \mathrm{~L}^{-1} \mathrm{NO}_{3} \mathrm{NH}_{4}, 0.4 \mathrm{mg} \mathrm{L}^{-1} \mathrm{CaCl}_{2}$, $0.4 \mathrm{mg} \mathrm{L}^{-1} \mathrm{FeSO}_{4}$, and $0.1 \mathrm{~mL}$ of solution containing $100 \mathrm{mg} \mathrm{L}^{-1}$ of $\mathrm{H}_{3} \mathrm{BO}_{4}, \mathrm{MnSO}_{4}$, $\mathrm{ZnSO}_{4}, \mathrm{CuSO}_{4}$, and $\mathrm{CoCl}_{2}$, and $20 \mathrm{~g} \mathrm{~L}^{-1}$ of agar. For each of the above soil dilutions, five replicate plates were inoculated with $0.25 \mathrm{~mL}$ each, and the plates were incubated at $30{ }^{\circ} \mathrm{C}$ for $48 \mathrm{~h}$ of $\mathrm{HB}$ and at $30{ }^{\circ} \mathrm{C}$ for 21 day of OUB. The bacterial colony numbers were counted, the mean values were obtained and taking the dilution factor into consideration, the total numbers of colony forming units (CFU) per gram dry soil were calculated.

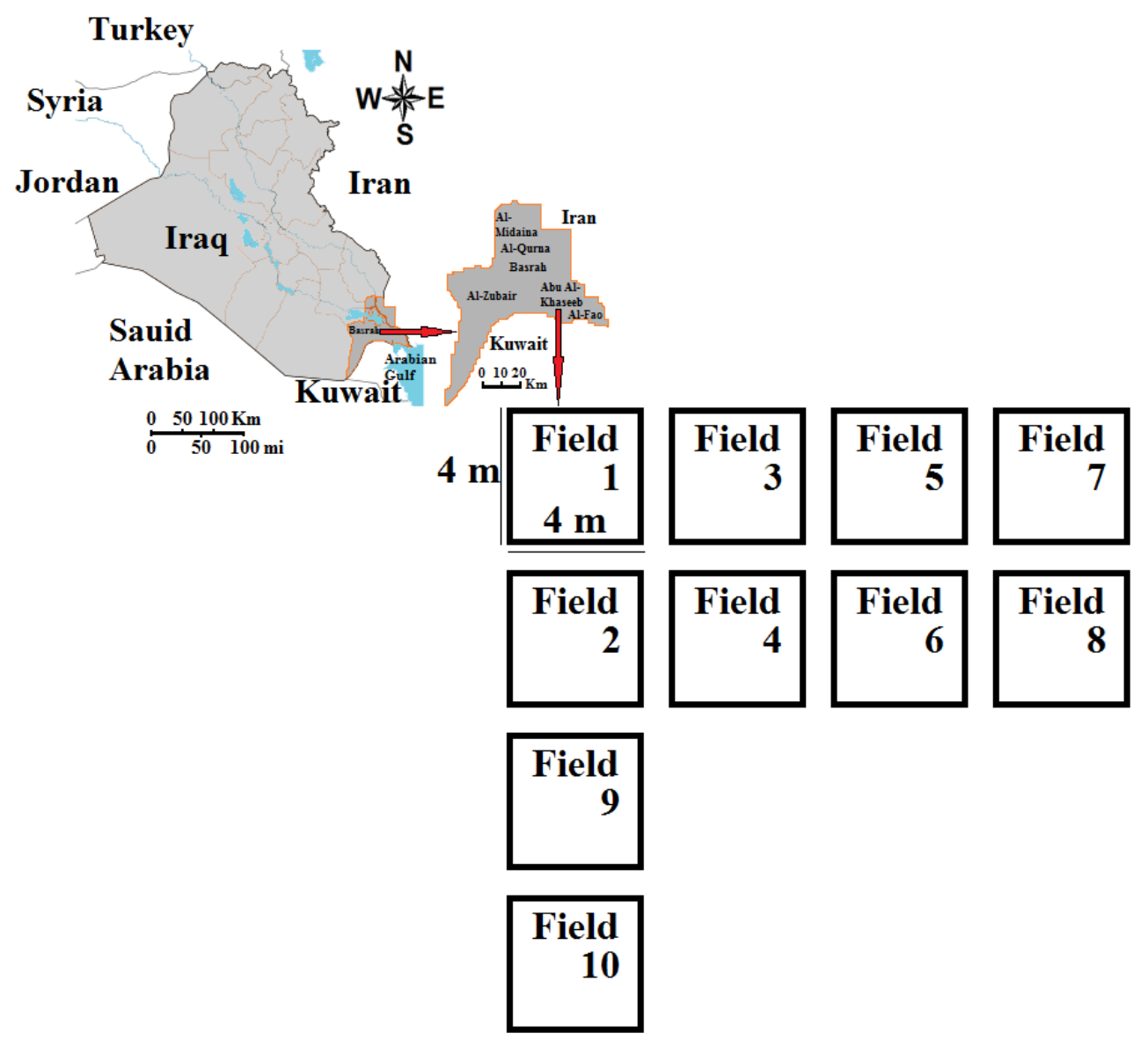

Figure 1. Map of study area and schematic representation of the layout of the accomplished site 
Table 1. The designed experimental fields and their additions

\begin{tabular}{c|c}
\hline Fields & Addition \\
\hline 1 & Without addition \\
2 & Fertilizer (NPK) \\
3 & Hay (Cynodon dactylon L.) \\
4 & Plastic pipes \\
5 & Bacteria (Bacillus cereus WR146) \\
6 & Fertilizer (NPK) + Plastic pipes \\
7 & Hay (Cynodon dactylon L.) + Plastic pipes \\
8 & Fertilizer (NPK) + Hay (Cynodon dactylon L.) + Plastic pipes \\
9 & Hay (Cynodon dactylon L.) + Plastic pipes + Bacteria (Bacillus cereus WR146) \\
10 & Fertilizer (NPK) + Hay (Cynodon dactylon L.) + Plastic pipes + Bacteria (Bacillus cereus WR146) \\
\hline
\end{tabular}

Table 2. Some environmental climatic factors for the current study area

\begin{tabular}{c|c|c}
\hline Factor & Monthly range & Annual average \\
\hline Solar radiation & 7.37 (January) - 13.16 (June) & 10.14 \\
Temperature $\left({ }^{\circ} \mathrm{C}\right)$ & 18.2 (January) -46.9 (August) & 33.75 \\
Precipitation $(\mathrm{mm})$ & $0-26.4$ (January) & 11.34 \\
Evaporation $(\mathrm{mm})$ & 277.3 (December) -3006.5 (July) & 1702.93 \\
Relative humidity $(\%)$ & 20.52 (June) -67.7 (January) & 40.35 \\
Wind speed $(\mathrm{m} / \mathrm{s})$ & 3 (October) $-5.6($ June $)$ & 3.73 \\
\hline
\end{tabular}

Table 3. Characteristics of the agricultural soil

\begin{tabular}{c|c|c}
\hline Property & Polluted & Unpolluted \\
\hline PH & 7.30 & 7.10 \\
Silt \% & 32.5 & 32.5 \\
Clay \% & 72.4 & 72.4 \\
Sand \% & 3.50 & 3.50 \\
Texture & Clay & Clay \\
Total Ca \% & 0.40 & 0.43 \\
TOC \% & 9.60 & 7.20 \\
$\mathrm{P}_{2} \mathrm{O}_{2} \%$ & 0.08 & 0.10 \\
$\mathrm{~K}_{2} \mathrm{O} \%$ & 0.18 & 0.12 \\
Total N \% & 0.009 & 1.00 \\
Particle density $\left(\mathrm{Mg} \mathrm{m}^{-3}\right)$ & --- & 1.5 \\
Bulk density $\left(\mathrm{Mg} \mathrm{m}^{-3}\right)$ & --- & 2.5 \\
Porosity \% & --- & 40.5 \\
Water Infiltration rate $\left(\mathrm{cm} \mathrm{h}^{-1}\right)$ & --- & 1.4 \\
Saturation hydraulic Conductivity $\left(\mathrm{m} \mathrm{day}^{-1}\right)$ & & 0.43 \\
Electrical conductivity $\left(\mathrm{ds} \mathrm{\textrm {m } ^ { - 1 }}\right)$ & --- & 7.60 \\
Temperature $\left({ }^{\circ} \mathrm{C}\right)$ & & 40 \\
Moisture: & & 27.9 \\
-Field capacity \% & --- & 17.5 \\
-Permanent wilting point \% & --- & 10.5 \\
\hline
\end{tabular}


Crude oil content in soil was determined by the method of Villalobos et al. (2008), a sample of $50 \mathrm{~g}$ was sieved through a $62 \mu \mathrm{m}$ stainless steel sieve, which was dried for $12 \mathrm{~h}$ at $105{ }^{\circ} \mathrm{C}$ and mechanically homogenized. Exactly $10 \mathrm{~g}$ of soil was placed in a dried and weighed round flask. Anhydrous sodium sulphate $(10 \mathrm{~g})$ was then added to the flask and $35 \mathrm{~mL}$ of $\mathrm{n}$-hexane were utilized for extraction process in a ultrasound bath. The extract was filtered over a column filled with $0.6 \mathrm{~g}$ of glass wool, $5 \mathrm{~g}$ of silica gel, and $1 \mathrm{~g}$ of celite respectively, and washed with $25 \mathrm{~mL}$ of $\mathrm{n}$-hexane. The $\mathrm{n}$-hexane was evaporated in a rotary evaporator and the residue of crude oil was then weighed. This execution was reiterated 3 time for each sample of soil to extract the most quantity of crude oil.

Soil microbial activity was estimated by measuring the concentration of carbon dioxide formed 10 days after incubation of samples of soil in glass-tight vessels in $20{ }^{\circ} \mathrm{C}$. Water was append to the soils by $50-60 \%$ of water holding capacity. Concentration of carbon dioxide in the head space was analyzed by a Shimadzu (GC-14, Japan) gas chromatography provided with a Thermal Conductivity Detector (TCD) in $60{ }^{\circ} \mathrm{C}$. The samples of gas were analyzed in $40{ }^{\circ} \mathrm{C}$ using of column $(2 \mathrm{~m})$ packed with Porapak Q with $\mathrm{He}$ as a carrier gas flowing at $40 \mathrm{~mL} \mathrm{~min}^{-1}$ rate. The gas analyses was achieved in triplicate. The values were expressed in $\mu \mathrm{g} \mathrm{CO}_{2} \mathrm{~g}^{-1}$ soil day ${ }^{-1}$ The difference in carbon dioxide formation between unpolluted soil and crude oil polluted one was utilized to estimate the degradation of crude oil.

Effect of fertilizers on biodegradation was laboratory assessed, $0.66 \mathrm{mg} \mathrm{g}^{-1}$ of urea (nitrogen source), $0.31 \mathrm{mg} \mathrm{g}^{-1}$ of superphosphate (phosphorus source), and oleophilic fertilizer S200 (developed by IEP Europe, Madrid, Spain) in dosage as described by IEP Europe, were added to soil samples and tested. The S200 containing nitrogen (7.9\%) and phosphorus $(0.6 \%)$, consisted of a microemulsion of a saturated solution of urea as a nitrogen source in oleic acid as a carrier, an oleophilic phosphate ester as a phosphorus source and surfactant, and a viscosity reducer. The critical micelle dilution (CMD) of S200 was estimated and the critical micelle concentration (CMC) was measured by the surface tension method. The surface tension measurements were done by duNouy ring method using a KSV Sigma 701 model tensiometer and platinum ring at $20{ }^{\circ} \mathrm{C}$ (Lima et al., 2017). The CMC was then determined by plotting surface tension as a function of the S200 concentrations. A range of concentrations under CMC were used to evaluate the impact of S200 on biodegradation.

Biosurfactant role created by B. cereus WR146 in the elimination of crude oil sorbed on the soil surface has been investigated. The isolate was grown on $50 \mathrm{~mL}$ of $\mathrm{MM}$ supplemented with crude oil $(1 \%, \mathrm{v} / \mathrm{v})$ in a Erlenmeyer flask $(250 \mathrm{ml})$ and was incubated at $37{ }^{\circ} \mathrm{C}$ for 4 days in an incubator shaker at $185 \mathrm{rpm}$. The bacterial cells were then harvested by centrifugation at $10,000 \times g$ for $10 \mathrm{~min}$. The resulting supernatant was examined for production of biosurfactant by oil spreading method and drop collapse test according to the method described by Barin et al. (2014) and Janaki et al. (2016) respectively. Surface tension measurement of biosurfactant positive sample was determined in a KSV Sigma 701 model tensiometer using the duNouy ring method at $23{ }^{\circ} \mathrm{C}$ (Lima et al., 2017). Emulsification ability of the sample was estimated by calculating $\mathrm{E}_{24}$ index (Hamzah et al., 2013). All the assays were performed in triplicate with distilled water as the control. The biosurfactant was purified by the centrifugation of culture broth at $12,000 \times g$ for $20 \mathrm{~min}$ and extracted twice with chloroform and methanol $(2: 1, \mathrm{v} / \mathrm{v})$. The solvents were evaporated by a rotary evaporator and the residue was purified in a silica gel (60-120 mesh) column. The sample was then eluted 
with chloroform and methanol $(20: 1$ to $2: 1 \mathrm{v} / \mathrm{v})$. The fractions were collected and the solvents were removed by evaporation, the resulting residue was dialysed with distilled water and lyophilized. The crude biosurfactant was expressed in $\mathrm{g} \mathrm{L}^{-1}$. The isolated biosurfactant was then characterized by estimation of the protein concentration (by total protein test kit from Supplimed International, India) (Rufino et al., 2014), the total carbohydrate content (by the phenol-sulphuric acid method) (Lobna and Ahmed, 2013), the fatty acids content (by gas chromatography) (Rufino et al., 2014), and the peptide groups (by Lowry test) (Lowry et al., 1951).

Fifty gram of washed sand was mixed with crude oil $(1 \mathrm{~g})$ in flasks $(250 \mathrm{~mL})$ and $100 \mathrm{~mL}$ of water was added. Different concentrations of crude biosurfactant extract $\left(0.001,0.01,0.1,0.15,1,1.5,3,6\right.$, and $\left.10 \mathrm{~g} \mathrm{~L}^{-1}\right)$ were prepared and then added to sand contaminated with crude oil in the flasks. The mixtures were shaken $(75 \mathrm{rpm})$ for 2 days at room temperature. Controls treatment without biosurfactant extract were achieved.

Statistical analysis of the data was done by ANOVA, with differences by the least significant differences method being determined at 5\% $(P<0.05)$. Statistical analysis was performed using SPSS 16.0 for Windows (IBM, Armonk, New York, USA).

\section{Results}

Table 4 shows the counts of $\mathrm{HB}$ and OUB in the I, II and III samples. The II sample generally contained the highest counts of HB and OUB. While the samples I and III contained a lower counts of HB and OUB respectively (Table 5). Figure 2 exhibits the temporal variation in the counts of HB and OUB in IV and V soil samples of the fields 1 and 10. The results indicated that the counts of HB did not show clear tendencies in fields 1 and 10. Nutrient supplementation and aeration were not necessary to increase bacterial counts. While the counts of OUB increases in field 10, but after a period of time, their counts are similar to the counts of bacteria in field 1 (Table 6).
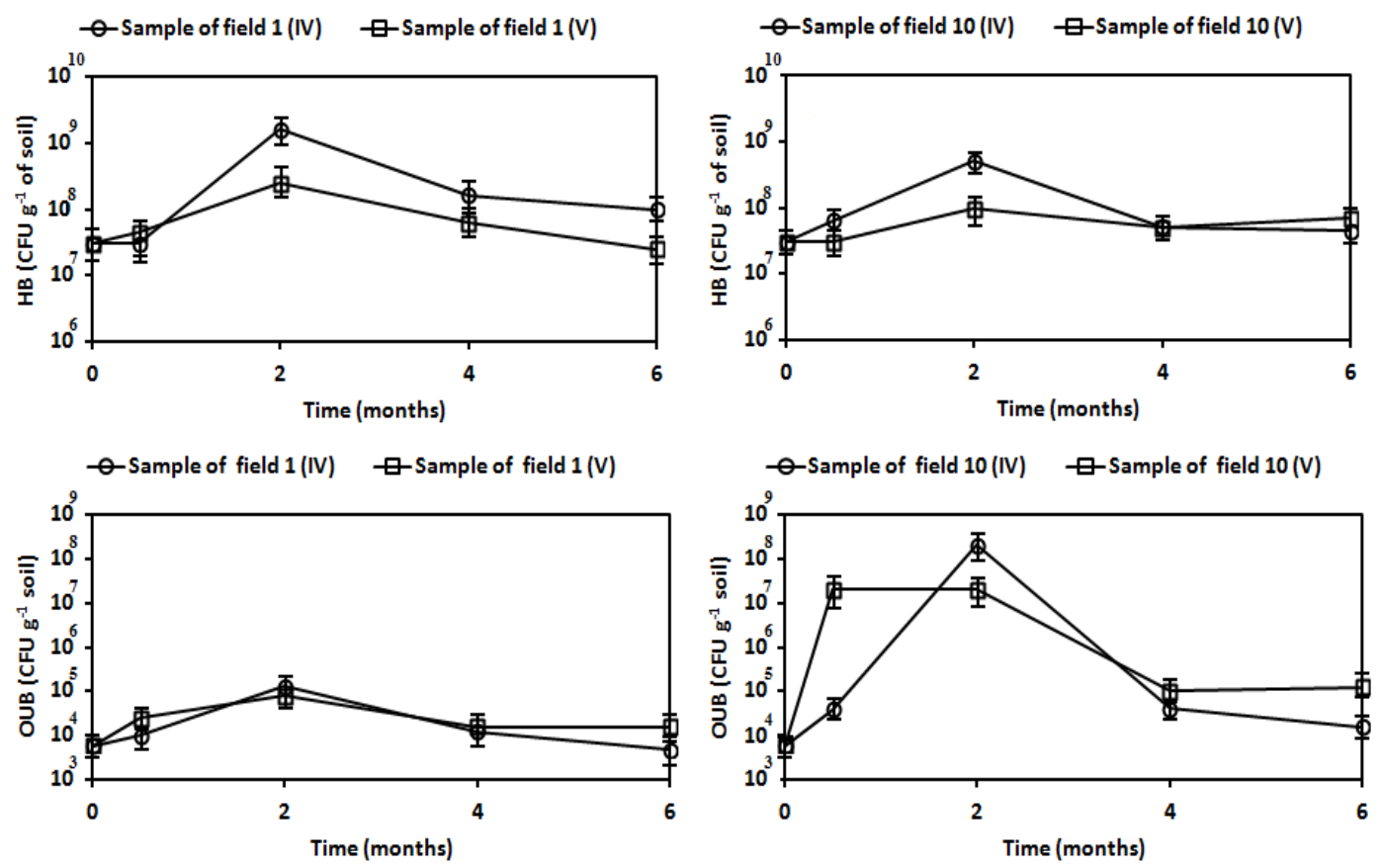

Figure 2. Temporal variations in the counts of $H B$ and $O U B$ in experimental fields. Error bars represent standard deviation (95\% confidence interval, C.I.) 
Table 4. Initial count of bacteria $\left(C F U g^{-1}\right)$ in the soil samples of the study area

\begin{tabular}{c|c|c}
\hline Soil sample & HB & OUB \\
\hline I & $4 \times 10^{8}$ & $7 \times 10^{6}$ \\
II & $5 \times 10^{9}$ & $4 \times 10^{7}$ \\
III & $2 \times 10^{7}$ & $5 \times 10^{4}$ \\
\hline
\end{tabular}

Table 5. Mean count of bacteria (HB and OUB) (CFU $\left.g^{-1}\right)$ in the soil samples (I, II and III) of the study area and $R L S D_{0.05}$ value

\begin{tabular}{c|c|c|c|c}
\hline \multicolumn{3}{|c|}{ Soil sample } & \multicolumn{2}{c}{ Bacteria } \\
\hline I & II & III & HB & OUB \\
\hline $6.1 \times 10^{7}$ & $4.7 \times 10^{8}$ & $5.1 \times 10^{6}$ & $4.9 \times 10^{7}$ & $6.0 \times 10^{6}$ \\
\hline \multicolumn{3}{c|}{} & \multicolumn{3}{c}{ RLSD $_{0.05}$} \\
& RLSD $_{0.05}$ & & \multicolumn{2}{c}{$1.4 \times 10^{5}$} \\
\hline
\end{tabular}

Table 6. Mean count of bacteria (HB and OUB) $\left(C F U g^{-1}\right)$ in the soil samples (IV and V) of experimental fields (1 and 10) over the time (month) and $R L S D_{0.05}$ value

\begin{tabular}{c|c|c|c}
\hline & $\mathbf{1}(\mathbf{I V})$ & $8.6 \times 10^{7}$ & \\
Soil sample & $\mathbf{1}(\mathbf{V})$ & $8.2 \times 10^{7}$ & RLSD $_{0.05}$ \\
(HB) & $\mathbf{1 0}(\mathbf{I V})$ & $8.3 \times 10^{7}$ & $2.3 \times 10^{6}$ \\
& $\mathbf{1 0}(\mathbf{V})$ & $8.5 \times 10^{7}$ & \\
\hline & $\mathbf{0}$ & $7.7 \times 10^{7}$ & \\
Time & $\mathbf{0 . 5}$ & $7.9 \times 10^{7}$ & RLSD $_{0.05}$ \\
(HB) & $\mathbf{2}$ & $7.8 \times 10^{7}$ & $2.7 \times 10^{6}$ \\
& $\mathbf{4}$ & $8.0 \times 10^{7}$ & \\
\hline \multirow{2}{*}{ Soil sample } & $\mathbf{6}$ & $8.1 \times 10^{7}$ & \\
(OUB) & $\mathbf{1}(\mathbf{I V})$ & $5.3 \times 10^{3}$ & $\mathrm{RLSD}_{0.05}$ \\
& $\mathbf{1}(\mathbf{V})$ & $4.8 \times 10^{4}$ & $2.2 \times 10^{4}$ \\
& $\mathbf{1 0}(\mathbf{I V})$ & $5.7 \times 10^{5}$ & \\
\hline Time & $\mathbf{1 0}(\mathbf{V})$ & $6.1 \times 10^{6}$ & \\
(OUB) & $\mathbf{0}$ & $5.3 \times 10^{3}$ & RLSD $_{0.05}$ \\
& $\mathbf{0 . 5}$ & $5.3 \times 10^{5}$ & $2.3 \times 10^{3}$ \\
& $\mathbf{2}$ & $6.7 \times 10^{6}$ & \\
\hline \multirow{2}{*}{ Bacteria } & $\mathbf{4}$ & $5.4 \times 10^{4}$ & RLSD $_{0.05}$ \\
& $\mathbf{6}$ & $8.6 \times 10^{4}$ & $1.5 \times 10^{5}$ \\
\hline
\end{tabular}

Crude oil content was measured in the soil samples obtained prior to the design of the experimental fields to gain an image of the average and highest grades of crude oil contamination in the study area. After the design of the fields, soil samples were collected from each field to acquire a zero-time determine of the crude oil concentration in the each field. There are apparent differences in the content of crude oil in the 
remediation fields because of their asymmetrical nature. Nevertheless, there is a obvious decline in crude oil content over time (Fig. 3). The results of the fields 1 and 10 indicated a reduce in crude oil content, with similarities in the rudimentary crude oil removal rates in both fields, which may be due to the elimination of volatile light compounds from the soil. After 3 months ago, crude oil was removed more in field 10 than field 1. No statistically significant differences were found in the elimination of crude oil from soil surface of fields 1 and 10 to illustrate the importance of bioaugmentation (Table 7). Low microbial effectiveness, estimated from the development of carbon dioxide in vitro was found in samples of surface soil. Figure 4 and Table 8 show variations in the development of carbon dioxide in $\mathrm{V}$ soil sample of all fields. Field 10 exhibited the highest degradation capability.

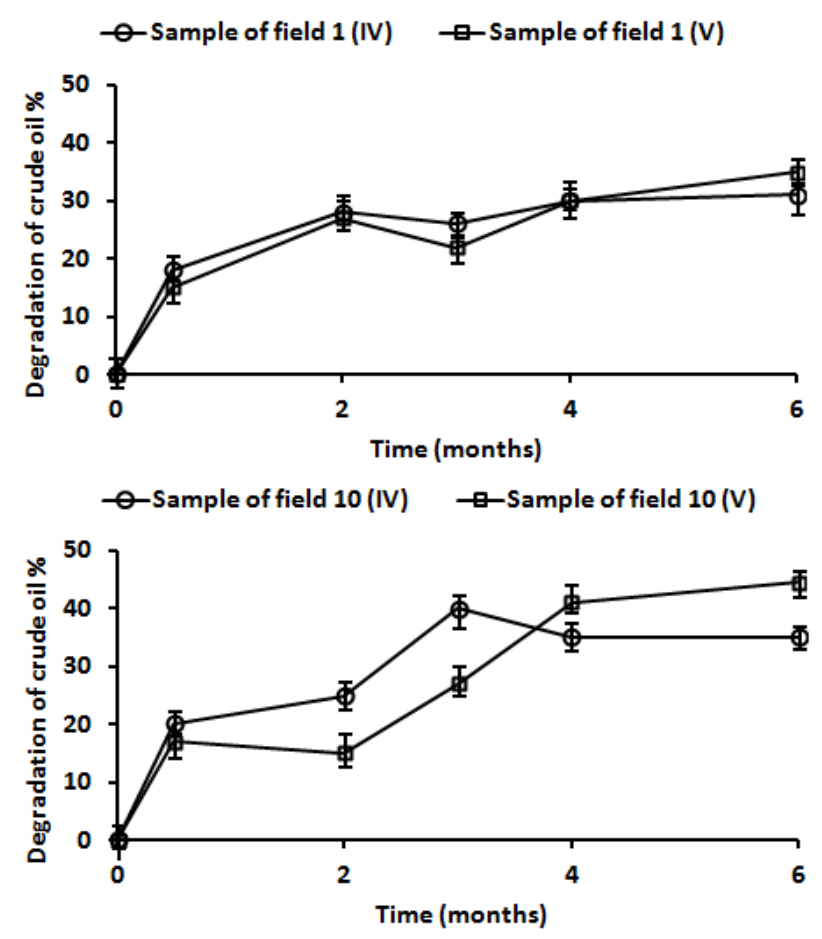

Figure 3. Percentage of crude oil degradation in experimental fields. Error bars represent standard deviation (95\% C.I.)

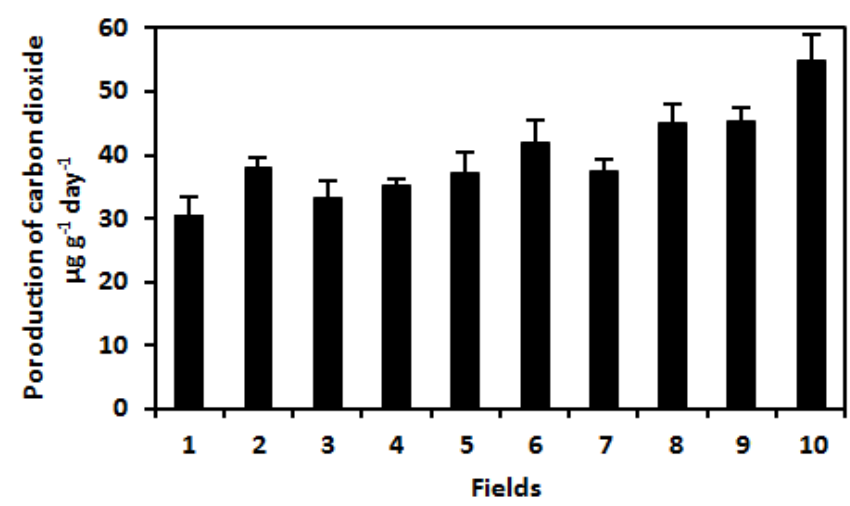

Figure 4. Carbon dioxide produced by microbial activity in the soil samples (V) of experimental fields. Error bars represent standard deviation (95\% C.I.) 
Table 7. Mean of crude oil degradation percentage in the soil samples (IV and V) of experimental fields (1 and 10) over the time (month) and RLSD 0.05 value

\begin{tabular}{c|c|c|c|c|c|c|c|c|c}
\hline \multicolumn{3}{c|}{ Soil sample } & \multicolumn{7}{c}{ Time } \\
\hline $\mathbf{1}(\mathbf{I V})$ & $\mathbf{1}(\mathbf{V})$ & $\mathbf{1 0}(\mathbf{I V})$ & $\mathbf{1 0}(\mathbf{V})$ & $\mathbf{0}$ & $\mathbf{0 . 5}$ & $\mathbf{2}$ & $\mathbf{3}$ & $\mathbf{4}$ & $\mathbf{6}$ \\
\hline 20.6 & 21.5 & 24.8 & 23.7 & 0 & 16.9 & 23.8 & 29.2 & 33.8 & 37.2 \\
\hline \multicolumn{3}{c|}{ RLSD $_{0.05}$} & \multicolumn{6}{c}{ RLSD $_{0.05}$} \\
3.12 & & \multicolumn{8}{c}{} \\
\hline
\end{tabular}

Table 8. Mean of carbon dioxide ( $\left.\mu g g^{-1} d a y^{-1}\right)$ produced by microbial activity in the soil samples $(V)$ of experimental fields (1-10) and RLSD 0.05 value

\begin{tabular}{c|c|c|c|c|c|c|c|c|c}
\hline \multicolumn{10}{c}{ Field } \\
\hline $\mathbf{1}$ & $\mathbf{2}$ & $\mathbf{3}$ & $\mathbf{4}$ & $\mathbf{5}$ & $\mathbf{6}$ & $\mathbf{7}$ & $\mathbf{8}$ & $\mathbf{8}$ & $\mathbf{1 0}$ \\
\hline 29.8 & 36.2 & 33.5 & 34.1 & 35.4 & 41.9 & 36.5 & 45.6 & 46.0 & 54.2 \\
\hline \multicolumn{10}{c}{ RLSD $_{0.05} 5.77$} \\
\hline
\end{tabular}

Table 9 exhibits the mean of alterations in crude oil content after three months of biological treatment in surface soil samples for all experimental fields. The proportion of crude oil content alterations in the soil has been transformed to daily rates of degradation of crude oil and carbon. The degradation was estimated depending on that content of carbon in crude oil ranges from 80-88\% (Eschrich, 1980). The theoretical carbon dioxide rates based on carbon degradation were higher than those obtained from laboratory experiments (Fig. 4), which may be due to the loss of crude oil in the fields by evaporation. The laboratory average rates of carbon dioxide development in crude oil polluted and unpolluted soils fertilized with nitrogen and phosphorus were 30.6$55.0 \mu \mathrm{g} \mathrm{g}^{-1} \mathrm{day}^{-1}$. The laboratory temperature was $22{ }^{\circ} \mathrm{C}$ while the temperature of the fields ranged from $34-37^{\circ} \mathrm{C}$. The results of carbon dioxide development at soil samples, IV and $\mathrm{V}$ indicate that the lowest microbial effectiveness was in the unpolluted soil and active degradation was found in the polluted one.

Table 9. Average changes in oil content over a three-month period of biological treatment in soil samples (IV) of experimental fields (2-10) and the rates of theoretical degradation

\begin{tabular}{c|c|c|c|c}
\hline & \multicolumn{4}{|c}{ Time (months) } \\
\cline { 2 - 5 } & $\mathbf{0}$ & $\mathbf{1}$ & $\mathbf{2}$ & $\mathbf{3}$ \\
\hline Content of oil $(\%)$ & 4.20 & 3.73 & 3.02 & 2.42 \\
Degradation of oil $\left(\mu \mathrm{g} \mathrm{g}^{-1} \mathrm{day}^{-1}\right)$ & --- & -- & -- & 43 \\
Degradation of carbon $\left(\mu \mathrm{g} \mathrm{g}^{-1} \mathrm{day}^{-1}\right)$ & -- & 126.2 & 190.1 & 31.8 \\
Production of carbon dioxide $\left(\mu \mathrm{g} \mathrm{g}^{-1} \mathrm{day}^{-1}\right)$ & --- & 534.1 & 700.2 & 116.4 \\
\hline
\end{tabular}

Adding S200 fertilizer to crude oil polluted soil with a less concentration than CMC improves the crude oil degradation process, while the addition of nitrogen and phosphorus only leads to higher degradation of crude oil. S200 fertilizer contains surfactant compound, an oleophile phosphate ester. The utilize of biosurfactant to liberation hydrocarbons sorbed on solid soil materials was less toxic than synthetic 
surfactants. The current study demonstrated that the biosurfactants produced by $B$. cereus WR146 had a high capacity to desorption of crude oil from the sand up to $100 \%$ at a concentration of 6 and $10 \mathrm{~g} \mathrm{~L}^{-1}$ of the biosurfactants (Fig. 5; Table 10). The use of synthetic surfactants would logically improve the production of biosurfactant in oilutilizing microbes, which are added or naturally found in the soil.

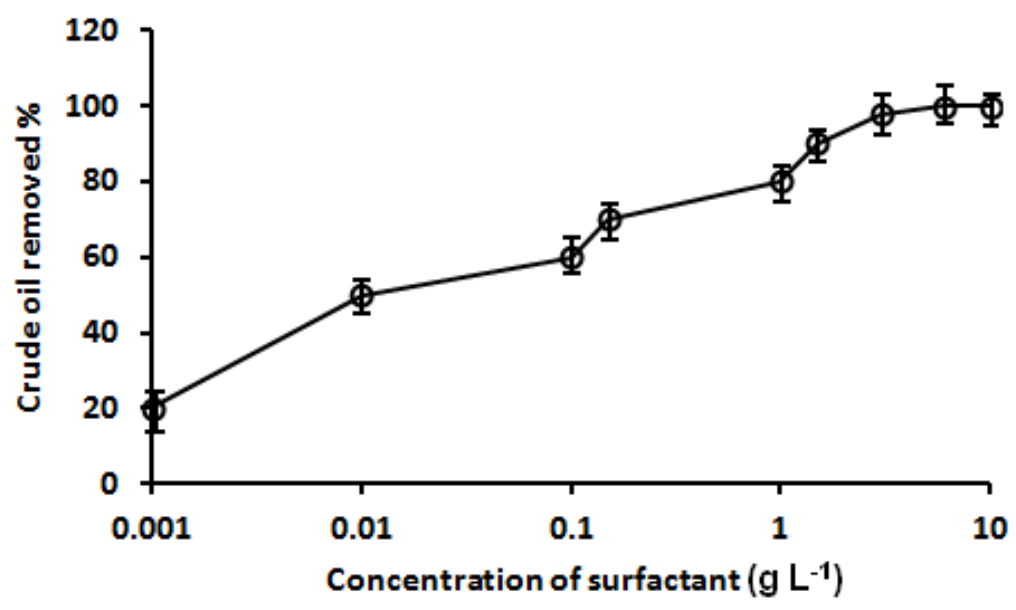

Figure 5. Effect of surfactant produced by B. cereus WR146 on the removal of crude oil from sand. Error bars represent standard deviation (95\% C.I.)

Table 10. Mean of percentage of crude oil removal from sand by different concentrations $\left(g L^{-1}\right)$ of surfactant produced by B. cereus WR146 and $R L S D_{0.05}$ value

\begin{tabular}{c|c|c|c|c|c|c|c|c}
\hline \multicolumn{10}{c}{ Concentration } \\
\hline $\mathbf{0 . 0 0 1}$ & $\mathbf{0 . 0 1}$ & $\mathbf{0 . 0 1}$ & $\mathbf{0 . 1 5}$ & $\mathbf{1}$ & $\mathbf{1 . 5}$ & $\mathbf{3}$ & $\mathbf{6}$ & $\mathbf{1 0}$ \\
\hline 21.3 & 49.7 & 61.9 & 74.9 & 81.6 & 89.3 & 97.5 & 99.8 & 100 \\
\hline \multicolumn{8}{c}{ RLSD $_{0.05}$} \\
7.04 \\
\hline
\end{tabular}

\section{Discussion}

Many large oil spill accidents in the marine environment have acquired considerable popularity in the media. While, smaller and more recurrent spills are often the most damaging to the ecosystem. Crude oil is not only directly toxic to organisms, but also has a suffocating impact (Buskey et al., 2016).

Bioremediation works, as documented in the literatures, may be confounding, especially when applied commercially. Where, there are predominatingly no endeavor to differentiate between the factors attributed to the success or fiasco of the process. Absolutely, each site has a unique case. All environmental factors such as weather, fertility of soil, $\mathrm{pH}$, type of soil, etc. have an important impact on bioremediation. Climate is particularly important in Iraq, which can be considered a bit extremist continental in most of its regions. In the summer, when the effectiveness of bioremediation process is at its top, is long, sweltering, arid, and clear, resulting to water drop in experimental fields. While, the Winter is cool, dry, and mostly clear. The site under study is an area of the crude oil spill incident, which covered about $500 \mathrm{~m}^{2}$ of agricultural land. The harmful impact of crude oil was on trees and other field crops, 
which were killed due to crude oil concentrations through their root area. Agricultural soil was polluted with crude oil almost at a depth of $50 \mathrm{~cm}$. The first solution to this trouble was to cover the crude oil polluted site with a surface layer of unpolluted soil.

In the present investigation, the compost system was used in bioremediation of crude oil in soil. This system has been works to improve rates of crude oil removal by biophysical methods. Where, a considerable removal of crude oil from polluted soil was observed after three months and reached 50\% relying on the type of compost system. The carbon dioxide development rates in the laboratory (Fig. 4) were lower than the theoretical rates of carbon dioxide estimated (Table 9), suggesting that a large amount of crude oil was disposed by ventilation process. The rates of lab for carbon dioxide development indicate the need for 6 years or more for the degradation of crude oil. This is in the case that $2.81 \%$ of the crude oil components in the soil can be degraded. Customary, the presence of many volatile fractions in the crude oil will decrease the time of biological treatment, however, the bioremediation of crude oil in the soil will remain very long without any treatment.

The primary degradation is quickly for certain hydrocarbons in the manipulating system. Analysis by gas chromatography of soil contaminated with crude oil exhibited the effective disposal of low molecular weight hydrocarbons over time. While some compounds such as polycyclic aromatic hydrocarbons (PAHs) need longer degradation time when suitable oil-utilizing microorganisms are exist. The degradation of these compounds may also want desorption from solid surfaces. The utilize of surfactant compounds for desorb hydrocarbon contaminants and impact on their microbial degradation has been exceedingly investigated. Non-ionic surfactants can increase the degradation of many PAHs in the watery phase (Zhu and Aitken, 2010; Zhentian et al., 2015; Yu et al., 2014). While, Alden et al. (2016) reported that non-ionic surfactants at a higher concentration than the CMC prevented degradation of PAHs. It has been shown that the capability of eight artificial surfactants to solubilize PAHs is varied. The most hydrophobic surfactants were more likely to solubilize PAHs. Whilst conflicting outcomes were gained from studying the biodegradation potential of PAHs solubilized by artificial surfactants (Adrion et al., 2016). The most hydrophobic surfactants were less endured by bacteria (Zheng et al., 2015). Barrios et al. (2005) and Zhu and Aitken (2010) demonstrated that Brij 30 degraded with naphthalene, while the Triton X-100 was not degraded. However, the addendum of the surfactants did not impact the degradation rate of naphthalene or the final quantity degraded, in spite of ameliorated bioavailability.

The S-200 fertilizer has been utilized in the biological treatment of heavy fuel oil spilled from the oil tanker Prestige in November 2002 along the Atlantic coast of Galicia (Spain). Our experiments with soil (non-existent results) exhibited that the crude oil biodegradation rates with S200 fertilizer are low compared to the use of urea and phosphorus only. Fertilizer, S200 is a microemulsion made up of an artificial surfactant that is probable to be an inhibitor in the concentrations applied. The value of half maximal effective concentration ( $\mathrm{EC}_{50}$ ) of S200 fertilizer (Microtox bioassy) was $0.3 \mathrm{mg} \mathrm{L}^{-1}$, which is more toxic than the $\mathrm{EC}_{50}$ value of biosurfactants produced by bacteria, Bacillus cereus WR146 (540 $\mathrm{mg} \mathrm{L}^{-1}$ ). Although the S200 fertilizer shows a inhibitory effect, it has the feature that the $\mathrm{S} 200$ in this oleophilic substrate does not wash readily from the soil.

Undoubtedly, the biosurfactants are lower toxic and more susceptible to microbial degradation than synthetic surfactants and are preferred in biological treatment. The production and employ of biosurfactants as raw extracts of microbial cultures or as purified materials is very costly. The biosurfactants can also be created from 
monosaccharides or sugar alcohols and fatty acids through esterification of enzymecatalysed in organic solvents (Satpute et al., 2010; Gumel et al., 2011). The growth of microorganisms that produce biosurfactants at the site would logically promote the desorption of hydrocarbon compounds. The present study exhibits that biosurfactants eliminate a large proportion of crude oil polluted to soil (non-existent results). The addition of biosurfactants-producing bacteria (B. cereus WR146) increases the removal of crude oil from the soil. This is reflected in soil samples taken from a depth of $50 \mathrm{~cm}$ from field 10, which displays the highest rates of carbon dioxide development (Fig. 5). It is necessary to evolve methods to increase the production of biosurfactants in the environment or introduce oil-utilizing microorganisms to the soil.

There are many factors that restrict the process of bioremediation in the term microbiology. The transfer of the organic contaminates mass from the soil particles to the liquid phase may be a restricting factor as previously explained, so synthetic and biosurfactants are used. Also, many enzymes embroiled in the bioremediation process require molecular oxygen. Therefore, the transfer of oxygen mass to the soil may be a critical factor in many cases. In the current bioremediation process, locally obtainable accessories have been utilized to attempt to help oxygen transfer.

An important aspect of bioremediation, which has acquired only a small amount of attentiveness, is that the microbiological restriction is likely to be due to the catabolite repression. When a assortment of carbon substrates are present, the bacterium will logically select the substrates that can be easily used. However, such substrates may be plentiful and the requisite bacteria are present, but the biodegradation of contaminants may not forward. There is some clue to suggest that Bacillus lack the catabolite repression of other bacteria. Actually, the presence of glucose may promote the microbial degradation of hydrocarbon pollutants (Xu et al., 2018). If this is the case, Bacillus will have a great characteristic over others, so the bacteria will be the ideal option in the bioaugmentation.

This study is destined to identify the effects of some commonly used methods to optimize treatment and stratify them more generally to other areas polluted with crude oil.

\section{Conclusions}

Based on the results of this research, it was concluded that a better outcome could be achieved for the biological treatment of crude oil polluted agricultural soil using the composting systems, good ventilation, nutrients and biosurfactants producing bacteria. The research also showed that a noticeable degradation of crude oil occurred after 3 months of bioremediation up to $50 \%$. Further studies to determine the effectiveness of bioremediation in oils polluted soil are needed.

Acknowledgements. The authors would like to thank the Marine Science Center and the College of Agriculture, University of Basrah and the College of Science, University of Bagdad for providing the laboratory facilities.

\section{REFERENCES}

[1] Adams, G. O., Fufeyin, P. T., Okoro, S. E., Ehinomen, I. (2015): Bioremediation, biostimulation and bioaugmention: a review. - International Journal of Environmental Bioremediation \& Biodegradation 3(1): 28-39. 
[2] Adrion, A. C., Nakamura, J., Shea, D., Aitken, M. D. (2016): Screening nonionic surfactants for enhanced biodegradation of polycyclic aromatic hydrocarbons remaining in soil after conventional biological treatment. - Environmental Science \& Technology 50(7): 3838-3845.

[3] Agarry, S. E., Ogunleye, O. (2012): Factorial designs application to study enhanced bioremediation of soil artificially contaminated with weathered Bonny light crude oil through biostimulation and bioaugmentation strategy. - Journal of Environmental Protection 3: 748-759.

[4] Alden, C. A., David, R. S., Jun, N., Damian, S., Michael, D. A. (2016): Improving polycyclic aromatic hydrocarbon biodegradation in contaminated soil through low-level surfactant addition after conventional bioremediation. - Environmental Engineering Science 33(9): 659-670.

[5] Ali, W. A. (2019): Biodegradation and phytotoxicity of crude oil hydrocarbons in an agricultural soil. - Chilean Journal of Agricultural Research 79(2): 266-277.

[6] Atlas, R. M., Hazen, T. C. (2011): Oil biodegradation and bioremediation: a tale of the two worst spills in U.S. history. - Environmental Science Technology 45: 6709-6715.

[7] Barin, R., Talebi, M., Biria, D., Beheshti, M. (2014): Fast bioremediation of petroleumcontaminated soils by a consortium of biosurfactant/bioemulsifier producing bacteria. International Journal of Environmental Science and Technology 11: 1701-1710.

[8] Barrios, N., Sivov, P., D'Andrea, D., Nunez, O. (2005): Conditions for Selective Photocatalytic Degradation of Naphthalene in TritonX-100 Water Solutions. International Journal of Chemical Kinetic 37(7): 414-419.

[9] Biache, C., Mansuy-Huault, L., Faure, P. (2014): Impact of oxidation and biodegradation on the most commonly used polycyclic aromatic hydrocarbon (PAH) diagnostic ratios: implications for the source identifications. - Journal of Hazardous Materials 267: 31-39.

[10] Biria, D., Maghsoudi, E., Roostaazad, R., Dadafarin, H., Lotfi, A. S., Amoozegar, M. A. (2010): Purification and characterization of a novel biosurfactant produced by Bacillus licheniformis MS3. - World Journal of Microbiology \& Biotechnology 26: 871-878.

[11] Boitsov, S., Petrova, V., Jensen, H. K. B., Kursheva, A., Litvinenko, I., Chen, Y., Klungsoyr, J. (2011): Petroleum related hydrocarbons in deep and subsurface sediments from South-Western Barents Sea. - Marine Environmental Research 71(5): 357-368.

[12] Buskey, E. J., White, H. K., Esbaugh, A. J. (2016): Impact of oil spills on marine life in the Gulf of Mexico: effects on plankton, nekton, and deep-sea benthos. - Oceanography 29(3): 174-181.

[13] Chee, K. Y., Shih, H. T. P. (2019): Cleaning contaminated soils by using microbial remediation: a review and challenges to the weaknesses. - American Journal of Biomedical Science \& Research 2(3): 126-128.

[14] Das, N., Chandran, P. (2011): Microbial degradation of petroleum hydrocarbon contaminants: an overview. - Biotechnology Research International 2011: 1-13.

[15] Eschrich, H. (1980): Properties and long term behavior of bitumer and radioactive waste bitumen mixtures. - Swedish Nuclear Fuel and waste Management Company (SKB) Technical Report TR 80-14.

[16] Eze, V. C., Onwuakor, C. E., Orok, F. E. (2014): Microbiological and physicochemical characteristics of soil contaminated with used petroleum products in Umuahia, Abia State, Nigeria. - Journal of Applied \& Environmental Microbiology 2(6): 281-286.

[17] Gennadiev, A. N., Pikovskii, Y. I., Tsibart, A. S., Smirnova, M. A. (2015): Hydrocarbons in soils: origin, composition, and behavior (review). - Eurasian Soil Science 48(10): 1076-1089.

[18] Gumel, A. M., Annuar, M. S. M., Heidelberg, T., Chisti, Y. (2011): Lipase mediated synthesis of sugar fatty acid esters. - Process Biochemistry 46: 2079-2090.

[19] Hamzah, A., Sabturani, N., Radiman, S. (2013): Screening and optimization of biosurfactant production by the hydrocarbon-degrading bacteria. - Sains Malaysiana 42(5): 615-623. 
[20] Ikuesan, F. A. (2017): Evaluation of crude oil biodegradation potentials of some indigenous soil microorganisms. - Journal of Scientific Research and Reports 13: 1-9.

[21] Ivshina, I. B., Kuyukina, M. S., Krivoruchko, A. V., Elkin, A. A., Makarov, S. O., Cunningham, C. J., Peshkur, T. A., Atlas, R. M., Philp, J. C. (2015): Oil spill problems and sustainable response strategies through new technologies. - Environmental Science Processes \& Impacts 17: 1201-1219.

[22] Jahangeer, Kumar, V. (2013): An overview on microbial degradation of petroleum hydrocarbon contaminants. - International Journal of Engineering and Technical Research 1: 34-37.

[23] Lima, R. A., Andrade, R. F. S., Rodríguez, D. M., Araújo, H. W. C., Santos, V. P., Campos-Takaki, G. M. (2017): Production and characterization of biosurfactant isolated from Candida glabrata using renewable substrates. - African Journal of Microbiology Research 11(6): 237-244.

[24] Lobna, A. M. and Ahmed, Z. A. (2013): Identification and characterization of biosurfactants produced by Rodococcus Equi and Bacillus Methlyotrophicus. - Journal of Biological Chemistry and Environmental Sciences 8(2): 341-358.

[25] Lowry, O. H., Rosebrough, N. J., Farr, A. L., Randall, R. J. (1951): Protein measurement with the folin phenol reagent. - Journal of Biological Chemistry 193: 265-275.

[26] Lukic, B. (2016): Composting of organic waste for enhanced bioremediation of PAHs contaminated soils. - Materials, Université Paris-Est, English NNT2016PESC1134: 1174.

[27] Ng, W., Malone, B. P., Minasny, B. (2017): Rapid assessment of petroleum-contaminated soils with infrared spectroscopy. - Geoderma 289: 150-160.

[28] Nwankwegu, A. S., Orji, M. U., Onwosi, C. O. (2016): Studies on organic and in-organic biostimulants in bioremediation of diesel-contaminated arable soil. - Chemosphere 162: 148-156.

[29] Pinedo, J., Ibanez, R., Primo, O., Gomez, P., Irabien, A., (2014): Preliminary assessment of soil contamination by hydrocarbon storage activities: main site investigation selection. - Journal of Geochemical Exploration B 147: 283-290.

[30] Prathyusha, K., Jagan Mohan, Y. S. Y. V., Sridevi, S., Sandeep, B. V. (2016): Isolation and characterization of petroleum hydrocarbon degrading indigenous bacteria from contaminated sites of Visakhapatnam. - International Journal of Advanced Research 4(3): 357-362.

[31] Ron, E. Z., Rosenberg, E. (2014): Enhanced bioremediation of oil spills in the sea. Current Opinion in Biotechnology 27: 191-194.

[32] Rufino, R. D., de Luna, J. M., de Campos Takaki, G. M., Sarubbo, L. A. (2014): Characterization and properties of the biosurfactant produced by Candida lipolytica UCP 0988. - Electronic Journal of Biotechnology 17: 34-38.

[33] Sari, G. L., Trihadiningrum, Y., Ni'matuzahroh (2019): Bioremediation of petroleum hydrocarbons in crude oil contaminated soil from Wonocolo public oilfields using aerobic composting with yard waste and rumen residue amendments. - Journal of Sustainable Development of Energy, Water and Environment systems 7(3): 482-492.

[34] Satpute, S. K., Banpurkar, A. G., Dhakephalkar, P. K., Banat, I. M., Chopade, B. A. (2010): Methods for investigating biosurfactants and bioemulsifiers: a review. - Critical Reviews in Biotechnology 30(2): 127-44.

[35] Šolevic, T., Novaković, M., Ilić, M., Antić, M., Vrvić, M. M., Jovančićević, B. (2011): Investigation of the bioremediation potential of aerobic zymogenous microorganisms in soil for crude oil biodegradation. - Journal of Serbian Chemical Society 76(3): 425-438.

[36] Tang, J., Lu, X., Sun, Q., Zhu, W. (2012): Aging effect of petroleum hydrocarbons in soil under different attenuation conditions. - Agriculture, Ecosystems and Environment 149: 109-117. 
[37] Varjani, S. J., Upasani, V. N. (2017): A new look on factors affecting microbial degradation of petroleum hydrocarbons pollutants. - International Biodeterioration and Biodegradation 120: 71-83.

[38] Villalobos, M., Avila-Forcada, A. P., Gutierrez-Ruiz, M. E. (2008): An improved gravimetric method to determine total petroleum hydrocarbons in contaminated soils. Water, Air, \& Soil Pollution 194: 151-161.

[39] Xu, X., Liu, W., Tian, S., Wang, W., Qi, Q., Jiang, P., Gao, X., Li, F., Li, H., Yu, H., (2018): Petroleum hydrocarbon-degrading bacteria for the remediation of oil pollution under aerobic conditions: a perspective analysis. - Frontiers Microbiology 9: 2885.

[40] Yu, H., Xiao, H., Wang, D. (2014): Effects of soil properties and biosurfactant on the behavior of PAHs in soil-water systems. - Environmental Systems Research 3: 6.

[41] Zheng, Y., Li, L., Shi, X., Huang, Z., Jianmin, Y., Guo, Y. (2018): Nonionic surfactants and their effects on asymmetric reduction of 2-octanone with Saccharomyces cerevisiae. - AMB Express 8: 111.

[42] Zhentian, S., Jiajun, C., Xue, Y. (2013): Effect of anionic-nonionic-mixed surfactant micelles on solubilization of PAHs. - Journal of the Air \& Waste Management Association 63(6): 694-701.

[43] Zhu, H., Aitken, M. D. (2010): Surfactant-enhanced desorption and biodegradation of polycyclic aromatic hydrocarbons in contaminated soil. - Environmental Science \& Technology 44(19): 7260-7265. 